\title{
Factors Associated with Complete Home Smoking Ban among Chinese Parents of Young Children
}

\author{
Kaiyong Huang ${ }^{1,+}{ }^{,}$Hailian Chen ${ }^{2,+}{ }^{,}$Jing Liao ${ }^{3}$, Guangmin Nong ${ }^{3}$, Li Yang ${ }^{1}$, \\ Jonathan P. Winickoff ${ }^{4}$, Zhiyong Zhang ${ }^{1}$ and Abu S. Abdullah ${ }^{5,6,7, *}$ \\ 1 School of Public Health, Guangxi Medical University, Nanning 530021, Guangxi, China; \\ huangka0319@sina.com (K.H.); yangli8290@hotmail.com (L.Y.); rpazz@163.com (Z.Z.) \\ 2 School of Information and Management, Guangxi Medical University, Nanning 530021, Guangxi, China; \\ chlq869007621@163.com \\ 3 Department of Pediatrics, The First Affiliated Hospital of Guangxi Medical University, Nanning 530021, \\ Guangxi, China; gxlmd@126.com (J.L.); ngm8525@hotmail.com (G.N.) \\ 4 MGH Center for Child and Adolescent Health Research and Policy, Harvard Medical School, Boston, \\ MA 02115, USA; JWINICKOFF@PARTNERS.ORG \\ 5 Global Health Program, Duke Kunshan University, Kunshan 215347, Jiangsu Province, China \\ 6 Duke Global Health Institute, Duke University, Durham, NC 27710, USA \\ 7 School of Medicine, Boston Medical Center, Boston University, Boston, MA 02118, USA \\ * Correspondence: asm.abdullah@graduate.hku.hk \\ + These authors contributed equally to this work.
}

Academic Editor: Paul B. Tchounwou

Received: 3 December 2015; Accepted: 21 January 2016; Published: 26 January 2016

\begin{abstract}
Background: The home environment is a major source of Environmental Tobacco Smoke (ETS) exposure among children especially in early childhood. ETS exposure is an important health risk among children and can cause severe and chronic diseases, such as asthma, bronchitis, and premature death. However, ETS exposure at home has often been neglected in the Chinese families. Identification of factors that facilitate or otherwise hamper the adoption of home smoking ban will help in the design and implementation of evidence-based intervention programs. This study identifies factors correlated with home smoking bans in Chinese families with children. (2) Methods: A cross-sectional survey of parents living in Nanning city, Guangxi Province, China with at least one smoker and a child in the household was conducted between September, 2013 and January, 2014. A Chi-square test was used to compare categorical variables differences between the parents who had home smoking bans and those with no home smoking ban. Multiple logistic regression analyses were used to identify factors correlated with home smoking bans. (3) Results: 969 completed questionnaires were collected with a response rate of $92.29 \%(969 / 1050)$. Of the respondents $(n=969)$, $14.34 \%$ had complete home smoking bans. Factors that were associated with home smoking bans were: having no other smokers in the family $(O R=2.173)$, attaining education up to high school $(O R=2.471)$, believing that paternal smoking would increase the risk of lower respiratory tract illnesses $(O R=2.755)$, perceiving the fact that smoking cigarettes in the presence of the child will hurt the child's health $(O R=1.547)$, believing that adopting a no smoking policy at home is very important $(O R=2.816)$, and being confident to prevent others to smoke at home $(O R=1.950)$. Additionally, parents who perceived difficulty in adopting a no smoking policy at home would not have a home smoking ban $(O R=0.523)$. (4) Conclusions: A home smoking ban is not widely adopted by families of hospitalized children in Guangxi Province, China. To protect the health of children, there is a need to develop and test interventions to promote home smoking bans. Factors identified as predictors of home smoking ban should be considered in the design of interventions.
\end{abstract}

Keywords: environmental tobacco smoke; home smoking ban; children; China 


\section{Introduction}

Secondhand Smoke (SHS) is defined as "the combination of smoke emitted from the burning end of a cigarette or other tobacco products and smoke exhaled by the smoker" [1]. Thirdhand smoke (THS) is a complex phenomenon resulting from residual tobacco smoke pollutants that adhere to the clothing and hair of smokers and to surfaces, furnishings, and dust in indoor environments [2]. Protano and Vitali proposed that "environmental tobacco smoke (ETS)" be used as a more inclusive term to describe any tobacco smoke exposure outside of active smoking [2], to describe SHS and THS. ETS is one of the most common and important sources of indoor air pollution in the home environment. An estimated 600,000 deaths each year worldwide are caused by ETS exposure, accounting to more than $1 \%$ of all deaths [3]. ETS exposure increases childrens' risk of having a carotid atherosclerotic plaque [4], respiratory tract infections, otitis media, asthma, and sudden infant death syndrome [5]. Eliminating indoor smoking practices in households can greatly protect children from the health effects of ETS exposure [6]. Study showed that the impact of at-home-smoking practices on children's ETS exposure is highlighted by the significant and progressive increases in urinary cotinine levels from children not living with smoker(s) to children living with smoker(s) who do not smoke at home to children living with smoker(s) who only smoke at home when the child is not there, and finally to children living with smoker(s) who smoke at home even if the child is in [7]. Implementing smoke-free policies in work places and public places have been proven to contribute to improving the public's knowledge of the harm of SHS exposure and changes in their smoking behavior, which could lead to increased adoption of voluntary home smoking bans $[6,8]$.

China is the largest producer and consumer of tobacco globally, with more than 350 million smokers [9] and 740 million non-smokers passively exposed to ETS exposure, including 180 million children under 15 years old [10,11]. ETS exposure is associated with an estimated 100,000 deaths annually in China [10]. The 2010 China Global Adult Tobacco Survey (GATS) reported that $67 \%$ of non-smokers are exposed to ETS in their homes, $73 \%$ in public places, $63 \%$ in work places, $58 \%$ in government buildings, and 37\% in schools [12]. Household ETS exposure rates in China were higher than in the United States [13], Korea [14], and Mexico [15]. Results from China National Behavior Monitoring, indicated the prevalence of ETS exposure in China persisted without any decline from 2002 to 2010 [8,16]. Since 2010, smoking bans policies have been gradually implemented in public areas including government buildings, public transportation, healthcare facilities, schools, workplaces, bars, and restaurants in China [17]. However, ETS exposure at home has often been neglected, despite being a major source of exposure to tobacco smoke among children, especially preschool children, who spent much of their time at home [18]. The low rates of home smoking ban in China, ranging between $6.3 \%-26 \%[19,20]$, indicate the fact that a large proportion of Chinese children are exposed to ETS at home, underscoring the need to identify factors that are associated with adopting home smoking bans. A home smoking ban is an effective, feasible, and relatively new measure to prevent ETS exposure among children. Studies have shown that implementation of a home smoking ban in families with a smoker will greatly reduce ETS (or SHS) exposure among children [21,22]. It is important to identify factors that facilitate or hamper the adoption of home smoking bans in order to develop intervention strategies to reduce ETS exposure for children in the home environment. Nevertheless, there are few studies that reported factors influencing the implementation of complete home smoking ban in China.

This study estimated the prevalence of home smoking bans in Guangxi Province, China, through a quantitative study of parents whose children were hospitalized in two major hospitals. The study identified factors correlated with hospitalized children's home smoking bans, and provided recommendations for implementing measures that promote home smoking bans. The home smoking ban considered in this study applies not only to parental smoking, but also to smoking by other cohabitants and visiting guests. 


\section{Methods}

\subsection{Design and Sample}

A cross-sectional study was conducted from September 2013 to January 2014 among children's parents attending in the pediatric in-patient departments of two grade-three hospitals in Nanning, Guangxi province: First Affiliated Hospital of Guangxi Medical University and the Nanning Maternal and Child Health Hospital. Grade 3 hospitals are general or comprehensive hospitals at the national, provincial, or city level (>500 beds) and has most of the medical and surgical specialties. Parents of hospitalized children in these two hospitals were approached for a face-to-face interview. A standardized Chinese language questionnaire was used to collect data. The questionnaire was developed with reference to the questionnaires previously used and validated by the investigato's team in China [23]. The modified questionnaire was pre-tested with 10 parents at Guangxi Medical University hospital for clarity and cultural acceptability. This required minor modification before finalization of the questionnaire. Trained research assistants conducted face to face interviews, using a structured questionnaire, to collect data from parents. Checks were carried out to ensure all the questions had been answered and incase of any discrepancies (unclear answers, unfinished questions, and/or logistic errors), the investigators contacted the individual by telephone or requested a re-interview when necessary. As a token of appreciation, each participant received a small gift. The study protocol was approved by the Ethical Committee of Guangxi Medical University (Number: 2013/ethics/SPH/03; dated, 15 March 2013) and informed consent was received from all individuals who agreed to participate in the study.

\subsection{Measures}

Data collection included demographic information (gender, age, ethnicity, education, income, and children's age) and smoking behavior (smoker, non-smoker). Questions asked to measure attitudes and practices about smoking policy and home smoking included: "How important is it for you to adopt a no smoking policy at home?" with response categories of "Very important, Important, Unsure, A little important, Not at all important"; "How much difficulty do you think you'll have adopting a no smoking policy at your home?" with response categories of "Very difficult, Difficult, Unsure, A little difficult, Not at all difficult"; "How confident are you that you would not allow others to smoke at your home?" with response categories of "Very confident, Confident, Unsure, A little confident, Not at all confident"; "How concerned are you that smoking cigarettes in the presence of your child will hurt your child's health?" with response categories of "Very concerned, Concerned, Unsure, A little concerned, Not at all concerned"; "Have you ever heard of third hand smoke" with response categories of "Yes or No", and other questions on "My being a smoker gets in the way of my being a parent", "Smoking in enclosed public places should be prohibited", "Breathing air in a room today where people smoked yesterday can harm the health of infants and children", and "Paternal smoking increases the risk of lower respiratory tract illnesses such as pneumonia in exposed children", with response categories of "Strongly agree, Agree, Disagree and Strongly disagree".

During analysis, responses were condensed into two categories each of "Very important/Important" and "Unsure/A little important/Not at all important", "Very difficult/Difficult" and "Unsure/A little difficult/Not at all difficult", "Very confident/Confident" and "Unsure/A little confident/Not at all confident", "Very concerned/Concerned" and "Unsure/A little concerned/Not at all concerned", "Strongly agree/Agree" and "Disagree/Strongly disagree" [24]. We defined "smoker" as those who smoked at the time of the survey, and defined "non-smoker" as those who never smoked or had quit smoking at the time of survey [25].

\subsection{Analyses}

Two members of the research team coded each questionnaire and entered all data in Epidata 3.1, and carried out data consistency checks. To examine the differences between the parents who had a 
home smoking ban and those without home smoking ban, a Chi-square test was performed. The factors with significant difference in chi-square test were included in multiple logistic regression analyses. The multiple logistic regression model was adjusted for age and sex. A $p$-value of $<0.05$ (two-tailed) was considered statistically significant. SPSS (version 13.0, IBM, New York, NY, USA) was used to conduct all statistical analyses.

\section{Results}

\subsection{Demographic and Other Characteristics Information}

A total of 969 participating parents successfully completed the questionnaires representing a response rate of $92.29 \%(969 / 1050)$. Of the respondents $(n=969), 68.83 \%$ were female, the majority $(89.88 \%)$ were under 45 years old, and $53.04 \%$ were ethnic Han. Only $18.99 \%$ of the respondents attained a college or higher level of education and $56.86 \%$ only received the nine-year compulsory education. The unemployment rate among the respondents was $42.72 \%$. Almost half $(49.74 \%)$ of the respondents had an annual household income below 3000CNY (about \$490) per month. 74.30\% children were under five years old. Overall, $16.82 \%$ of the respondents were smokers, and $56.76 \%$ had one or more smokers living in the same household. (Table 1).

Table 1. Characteristics of participating parents $(N=969)$.

\begin{tabular}{|c|c|}
\hline Variables & $N(\%)$ \\
\hline \multicolumn{2}{|l|}{ Gender } \\
\hline Male & $302(31.17 \%)$ \\
\hline Female & $667(68.83 \%)$ \\
\hline \multicolumn{2}{|l|}{ Age } \\
\hline $18-30$ & $406(41.89 \%)$ \\
\hline $31-44$ & $465(47.99 \%)$ \\
\hline Above 45 & $98(10.12 \%)$ \\
\hline \multicolumn{2}{|l|}{ Ethnicity } \\
\hline Han & $514(53.04 \%)$ \\
\hline Other ethnicities & $455(46.96 \%)$ \\
\hline \multicolumn{2}{|l|}{ Education } \\
\hline Below high school & $551(56.86 \%)$ \\
\hline High school graduate & $234(24.15 \%)$ \\
\hline College or above & $184(18.99 \%)$ \\
\hline \multicolumn{2}{|l|}{ Income per month } \\
\hline Below $3000 \mathrm{CNY}$ & $482(49.74 \%)$ \\
\hline 3000-6000 CNY & $331(34.17 \%)$ \\
\hline Above $6000 \mathrm{CNY}$ & $156(16.09 \%)$ \\
\hline \multicolumn{2}{|l|}{ Children's age } \\
\hline Under 5 years & $720(74.30 \%)$ \\
\hline 5 years or above & $249(25.70 \%)$ \\
\hline \multicolumn{2}{|l|}{ Other smokers in home } \\
\hline None & $419(43.24 \%)$ \\
\hline One or more & $550(56.76 \%)$ \\
\hline \multicolumn{2}{|l|}{ Smoking behavior } \\
\hline Smoker & $163(16.82 \%)$ \\
\hline Non-smoker & $806(83.18 \%)$ \\
\hline \multicolumn{2}{|c|}{ Having complete home smoking ban } \\
\hline Yes & $139(14.34 \%)$ \\
\hline No & $830(85.66 \%)$ \\
\hline
\end{tabular}




\subsection{Factors Associated with Complete Home Smoking Ban}

$14.34 \%(139 / 969)$ of the respondents reported that they had complete home smoking bans. Variables that showed significant bivariate associations with complete home smoking bans included: participating parents' gender $\left(\chi^{2}=6.947, p=0.008\right)$, education $\left(\chi^{2}=26.118, p<0.001\right)$, income $\left(\chi^{2}=7.209, p=0.027\right)$, whether have other smokers at home or not $\left(\chi^{2}=37.032, p<0.001\right)$, and is the participant a smoker? $\left(\chi^{2}=7.776, p=0.006\right)$. Compared with participating parents without a complete home smoking ban, participating parents' attitudes and practices about home smoking ban yielded the following results: "Paternal smoking increases the risk of lower respiratory tract illnesses such as pneumonia in exposed children" $\left(\chi^{2}=4.748, p=0.029\right)$, "How concerned are you that smoking cigarettes in the presence of your child will hurt your child's health?" $\left(\chi^{2}=75.688, p<0.001\right)$, "How important is it for you to adopt a no smoking policy at home" $\left(\chi^{2}=10.396, p=0.001\right)$, "How much difficulty do you think you'll have adopting a no smoking policy at your home" $\left(\chi^{2}=34.559, p<0.001\right)$, and "How confident are you that you would not allow others to smoke at your home" $\left(\chi^{2}=37.291\right.$, $p<0.001$ ) showed significant differences. (Table 2).

Table 2. Complete home smoking bans by selected characteristics $(N=139)$.

\begin{tabular}{|c|c|c|c|}
\hline Variables & $\begin{array}{l}\text { Complete Home } \\
\text { Smoking Ban } N(\%)\end{array}$ & $x^{2}$ & $p$ \\
\hline \multicolumn{4}{|l|}{ Gender } \\
\hline Male & $30(3.09 \%)$ & \multirow[b]{2}{*}{6.947} & \multirow[b]{2}{*}{$0.008^{a}$} \\
\hline Female & $109(11.25 \%)$ & & \\
\hline \multicolumn{4}{|l|}{ Age } \\
\hline $18-30$ & $51(5.25 \%)$ & \multirow{3}{*}{1.818} & \multirow{3}{*}{$0.403^{a}$} \\
\hline $31-44$ & $73(7.52 \%)$ & & \\
\hline Above 45 & $15(1.57 \%)$ & & \\
\hline \multicolumn{4}{|l|}{ Ethnicity } \\
\hline Han & $72(7.43 \%)$ & \multirow[b]{2}{*}{0.101} & \multirow{2}{*}{$0.750^{\mathrm{a}}$} \\
\hline Other ethnicities & $67(6.91 \%)$ & & \\
\hline \multicolumn{4}{|l|}{ Education } \\
\hline Under high school & $52(5.37 \%)$ & \multirow{3}{*}{26.118} & \multirow{3}{*}{$<0.001^{a}$} \\
\hline High school graduate & $45(4.64 \%)$ & & \\
\hline College or above & $42(4.33 \%)$ & & \\
\hline \multicolumn{4}{|l|}{ Income } \\
\hline Below 3000CNY per month & $65(6.71 \%)$ & \multirow{3}{*}{7.209} & \multirow{3}{*}{$0.027^{a}$} \\
\hline 3000-6000CNY per month & $41(4.23 \%)$ & & \\
\hline Above $6000 \mathrm{CNY}$ per month & $33(3.40 \%)$ & & \\
\hline \multicolumn{4}{|l|}{ Children's age } \\
\hline Under 5 years & $98(10.11 \%)$ & \multirow[b]{2}{*}{1.227} & \multirow[b]{2}{*}{$0.268^{a}$} \\
\hline 5 years or above & $41(4.23 \%)$ & & \\
\hline \multicolumn{4}{|l|}{ Other smokers at home } \\
\hline None & $93(9.59 \%)$ & \multirow{2}{*}{37.032} & \multirow{2}{*}{$<0.001^{a}$} \\
\hline More than 1 & $46(4.75 \%)$ & & \\
\hline \multicolumn{4}{|l|}{ Smoking behavior } \\
\hline Smoker & $12(1.24 \%)$ & \multirow{2}{*}{7.776} & \multirow{2}{*}{$0.006^{\mathrm{a}}$} \\
\hline Non-smoker & $127(13.10 \%)$ & & \\
\hline \multicolumn{4}{|c|}{ My being a smoker gets in the way of my being a parent } \\
\hline Strongly agree/Agree & $130(13.42 \%)$ & \multirow[b]{2}{*}{0.420} & \multirow[b]{2}{*}{$0.517^{\mathrm{a}}$} \\
\hline Disagree/Strongly disagree & $9(0.92 \%)$ & & \\
\hline
\end{tabular}


Table 2. Cont.

\begin{tabular}{|c|c|c|c|}
\hline Variables & $\begin{array}{l}\text { Complete Home } \\
\text { Smoking Ban } N(\%)\end{array}$ & $x^{2}$ & $p$ \\
\hline \multicolumn{4}{|c|}{ Smoking in enclosed public places should be prohibited } \\
\hline Strongly agree/Agree & $138(14.24 \%)$ & \multirow[b]{2}{*}{0.600} & \multirow[b]{2}{*}{$0.439^{a}$} \\
\hline Disagree/Strongly disagree & $1(0.10 \%)$ & & \\
\hline \multicolumn{4}{|l|}{$\begin{array}{l}\text { Breathing air in a room today where people smoked } \\
\text { yesterday can harm the health of infants and children }\end{array}$} \\
\hline Strongly agree/Agree & $127(13.11 \%)$ & \multirow[b]{2}{*}{1.112} & \multirow[b]{2}{*}{$0.292^{\mathrm{a}}$} \\
\hline Disagree/Strongly disagree & $12(1.23 \%)$ & & \\
\hline \multicolumn{4}{|c|}{$\begin{array}{l}\text { Paternal smoking increases the risk of lower respiratory } \\
\text { tract illnesses such as pneumonia in exposed children. }\end{array}$} \\
\hline Strongly agree/Agree & $132(13.62 \%)$ & \multirow[b]{2}{*}{4.748} & \multirow[b]{2}{*}{$0.029^{a}$} \\
\hline Disagree/Strongly disagree & $7(0.72 \%)$ & & \\
\hline \multicolumn{4}{|l|}{$\begin{array}{l}\text { How concerned are you that smoking cigarettes in the } \\
\text { presence of your child will hurt your child's health? }\end{array}$} \\
\hline Very concerned/Concerned & $105(10.83 \%)$ & \multirow[b]{2}{*}{75.668} & \multirow[b]{2}{*}{$<0.001^{\mathrm{a}}$} \\
\hline Unsure/A little concerned/Not at all concerned & $34(3.51 \%)$ & & \\
\hline \multicolumn{4}{|c|}{$\begin{array}{l}\text { How important is it for you to adopt a no smoking policy } \\
\text { at home }\end{array}$} \\
\hline Very important/Important & $129(13.31 \%)$ & \multirow[b]{2}{*}{10.396} & \multirow{2}{*}{$0.001^{\mathrm{a}}$} \\
\hline Unsure/A little important/Not at all important & $10(1.03 \%)$ & & \\
\hline \multicolumn{4}{|c|}{$\begin{array}{l}\text { How much difficulty do you think you'll have adopting a } \\
\text { no smoking policy at your home }\end{array}$} \\
\hline Very difficult/Difficult & $29(2.99 \%)$ & \multirow[b]{2}{*}{34.559} & \multirow[b]{2}{*}{$<0.001^{a}$} \\
\hline Unsure/A little difficult/Not at all difficult & $110(11.35 \%)$ & & \\
\hline \multicolumn{4}{|c|}{$\begin{array}{l}\text { How confident are you that you would not allow others to } \\
\text { smoke at your home }\end{array}$} \\
\hline Very confident/Confident & $84(8.67 \%)$ & \multirow[b]{2}{*}{3.049} & \multirow[b]{2}{*}{$<0.001^{\mathrm{a}}$} \\
\hline Unsure/A little confident/Not at all confident & $55(5.67 \%)$ & & \\
\hline \multicolumn{4}{|l|}{ Have you ever heard of third hand smoke } \\
\hline Yes & $31(3.19 \%)$ & \multirow[b]{2}{*}{3.788} & \multirow[b]{2}{*}{$0.052^{\mathrm{a}}$} \\
\hline No & $108(11.15 \%)$ & & \\
\hline
\end{tabular}

\subsection{Multiple Logistic Regression Analysis to Identify Predictors of Having a Complete Home Smoking Ban}

As shown in Table 3, factors that were associated with home smoking bans based on the results of the multiple logistic regression analysis included: having no other smokers in the family $(O R=2.173)$, graduating from high school $(O R=2.471)$, believing that paternal smoking would increase the risk of lower respiratory tract illnesses $(O R=2.755)$, perceiving the fact that smoking cigarettes in the presence of child will hurt child's health $(O R=1.547)$, believing that adopting a no smoking policy at home is very important $(O R=2.816)$, and being confident to prevent others to smoke at home $(O R=1.950)$. Additionally, parents who perceived difficulty in adopting a no smoking policy at home would not have a home smoking ban $(O R=0.523)$.

\section{Discussion}

In this study, the prevalence of home smoking bans reported by parents of hospitalized children was $14.34 \%$, which is much lower than the reported prevalence of $38 \%$ among Chinese Americans [26] and $26 \%$ in Shanghai, China [19]. A possible explanation of low home smoking bans in the current study could be that smoke-exposed children may be more likely to be hospitalized. Guangxi, being an underdeveloped area, most of the people were committed to improving their poverty status and many 
use tobacco to relieve stress or social interactions, and unlikely to take any self-initiated measure to reduce exposure to ETS [27]. Possible explanations are a lack of parental awareness or concern about the negative effects of ETS exposure on children, less-established social norms for protecting children from ETS exposure, and a traditional Chinese culture that reinforces obedience and prevents children from disagreeing with or complaining to parents about smoking [19]. Therefore, we may predict that the implementation rate of household smoking ban of average family in Guangxi is below than the rate at the national or global level.

Demographic information indicated that income and participating parents' smoking status were significantly related to having a home ban in bivariate, but not multivariate, analyses. Household smoking restrictions were all associated with gender, education, and the existence of other smokers at home in both bivariate and multivariate analyses. The results showed that women were more likely to live in households with complete bans than men (11.25\% vs. 3.09\%), contradicting the findings of an earlier study among Chinese Americans [25]. However, cultural norms that Chinese women are often treated based on stereotypical roles in the household as mother, daughter in-law, wife, or daughter, rather than on their needs and desires as distinct individuals [23], may dictate that women have less control over setting this type of policy in the home, and female non-smokers are more likely than male non-smokers to live with a smoker. This finding requires further exploration but suggests that ETS exposure reduction interventions need to be developed and tested, putting into consideration Chinese cultural norms [25]. At the same time, it is important to empower women to become advocates for a home environment free of the harmful effects of ETS exposure [28].

Table 3. Logistic regression model to identify predictors of having a complete home smoking ban.

\begin{tabular}{|c|c|c|}
\hline Variables & Adjusted OR & $95 \% \mathrm{CI}$ \\
\hline \multicolumn{3}{|l|}{ Income per month } \\
\hline Below 3000CNY & 1.000 & Reference \\
\hline 3000-6000CNY & 0.867 & $0.485,1.547$ \\
\hline Above $6000 \mathrm{CNY}$ & 1.453 & $0.816,2.584$ \\
\hline \multicolumn{3}{|l|}{ Education } \\
\hline Below high school & 1.000 & Reference \\
\hline High school graduate & 2.471 & $1.374,4.445$ \\
\hline College or above & 1.125 & $0.646,1.960$ \\
\hline \multicolumn{3}{|l|}{ Smoking behavior } \\
\hline Smoker & 0.896 & $0.391,2.053$ \\
\hline Non-smoker & 1.000 & Reference \\
\hline \multicolumn{3}{|l|}{ Other smokers at home } \\
\hline None & 2.173 & $1.405,3.361$ \\
\hline More than 1 & 1.000 & Reference \\
\hline \multicolumn{3}{|c|}{$\begin{array}{l}\text { Paternal smoking increases the risk of lower respiratory tract } \\
\text { illnesses such as pneumonia in exposed children }\end{array}$} \\
\hline Strongly agree/Agree & 2.755 & $1.149,6.607$ \\
\hline Disagree/Strongly disagree & 1.000 & Reference \\
\hline \multicolumn{3}{|c|}{$\begin{array}{l}\text { How concerned are you that smoking cigarettes in the presence of } \\
\text { your child will hurt your child's health? }\end{array}$} \\
\hline Very concerned/Concerned & 1.547 & $1.250,3.495$ \\
\hline Unsure/A little concerned/Not at all concerned & 1.000 & Reference \\
\hline \multicolumn{3}{|c|}{ How important is it for you to adopt a no smoking policy at home } \\
\hline Very important/Important & 2.816 & $1.316,6.025$ \\
\hline Unsure/A little important/Not at all important & 1.000 & Reference \\
\hline \multicolumn{3}{|c|}{$\begin{array}{l}\text { How much difficulty do you think you'll have adopting a no } \\
\text { smoking policy at your home }\end{array}$} \\
\hline Very difficult/Difficult & 0.523 & $0.316,0.863$ \\
\hline Unsure/A little difficult / Not at all difficult & 1.000 & Reference \\
\hline \multicolumn{3}{|c|}{$\begin{array}{l}\text { How confident are you that you would not allow others to smoke at } \\
\text { your home }\end{array}$} \\
\hline Very confident/Confident & 1.950 & $1.260,3.016$ \\
\hline Unsure/A little confident/Not at all confident & 1.000 & Reference \\
\hline
\end{tabular}


Some researchers have reported that indoor household smoking bans are less common among low-income households, and attributed this relationship to the fact that those with higher incomes had higher educational attainment and were more aware of the hazards of SHS exposure [28,29]. Our study found that household income level was negatively associated with household smoking ban, after considering all the factors in multivariate analyses. Chinese nine-year compulsory education rarely involves knowledge of the health hazards of tobacco, but previous study [30] found that education regarding the impact of SHS exposure on children and adolescents may impact future family practices around smoking in the home. Thus, we obtained that the higher the education levels, the greater possibility of the family tobacco control measures. Our findings which were consistent with the previous study [31] showed that adults and children of Chinese descent living in households with one or more smokers (including the respondent) were less likely to experience home smoking restriction than their counterparts who did not live with smokers. This indicates the need to educate smoker household members with targeted messages about the importance of and need to adopt home smoking bans.

Similar to previous studies [26,32], this study shows that individual awareness of the harms of ETS exposure plays a protective role regarding implementation of home smoking bans. The largest gains in home smoking bans occurred in families with the youngest children. This suggests that campaigns encouraging parents not to smoke around babies have been very effective. These benefits of home smoking bans include reducing ETS exposure among children and adults [7], promoting anti-smoking attitudes among youth, decreasing smoking and smoking uptake in teenagers and increasing quitting [33-36].

One limitation of the current study is that we recruited parents of hospitalized children from two grade-three hospitals in Guangxi, which may not represent the characteristics of participating parents attending in grade 1 or 2 hospitals, as well as the non-hospitalized population. The grade-three hospital in China is the best hospital with the highest qualified doctors and nurses, greatest medical service and management, best medical quality and safety, most advanced technical level, and efficiency. The grade-three hospital is better than the grade-two hospital, and the grade-two hospital is better than the grade-one hospital in all quality measures.

\section{Conclusions}

The findings of this study show that home smoking ban is not widely adopted by families of hospitalized children in Guangxi, China, which underscores the fact that many children are exposed to ETS at home. Several factors including parental misconceptions about the harms of smoking and ETS exposure and lack of awareness about the usefulness of home smoking ban was associated with not adopting smoke-free home policies. Tobacco control programs, primarily designed to minimize spread of, and exposure, to ETS, should be used to promote and strengthen the public awareness of added benefits achievable through home smoking restrictions in addition to dispelling their misconceptions about smoking and ETS.

Acknowledgments: The authors thank the study participating parents. This study was supported by a grant (principal investigator: Abu S. Abdullah) from the Flight Attendant Medical Research Institute, USA, to the American Academy of Pediatrics (AAP), Julius B. Richmond Center.

Author Contributions: Kaiyong Huang drafted the manuscript, carried out the acquisition, analysis and interpretation of the data, and approved the final manuscript as submitted. Hailian Chen carried out the analysis and interpretation of the data, and drafted parts of the manuscript. Abu S. Abdullah conceptualized and designed the whole study, supervised and instructed data collection and analysis, reviewed and revised the manuscript, and approved the final manuscript as submitted. Jing Liao coordinated and supervised data collection, carried out the initial analyses. Guangmin Nong and Li Yang contributed to the overall design of the study, commented on the data collection instrument, and critically reviewed the manuscript. Jonathan P. Winickoff contributed to the overall design of the study, critically reviewed the manuscript. Zhiyong Zhang contributed to the overall design of the study and data interpretation.

Conflicts of Interest: The authors declare no conflict of interest. 


\section{References}

1. World Health Organization. Policy Recommendations on Protection from Exposure to Second-hand Tobacco Smoke; World Health Organization: Geneva, Switzerland, 2007.

2. Protano, C.; Vitali, M. The new danger of thirdhand smoke: Why passive smoking does not stop at secondhand smoke. Environ. Health Perspect. 2011, 119. [CrossRef] [PubMed]

3. World Health Organization. Tobacco, Fact Sheet. Available online: http://www.who.int/mediacentre/ factsheets/fs339/en/ (accessed on 29 December 2015).

4. Klonoff-Cohen, H.S.; Edelstein, S.L.; Lefkowitz, E.S.; Srinivasan, I.P.; Kaegi, D.; Chang, J.C.; Wiley, K.J. The effect of passive smoking and tobacco exposure through breast milk on sudden infant death syndrome. JAMA 1995, 273. [CrossRef]

5. Juonala, M.; Gall, S.L.; Kähönen, M.; Laitinen, T.; Taittonen, L.; Viikari, J.S.A.; Raitakari, O.T.; Magnussen, C.G. Exposure to parental smoking in childhood is associated with increased risk of carotid atherosclerotic plaque in adulthood: The cardiovascular risk in young Finns study. Circulation 2015, 131. [CrossRef]

6. Pinpin, Z.; Michelle, C.K.; Carla, J.B.; Wenjie, F.; Jing, W.; Xilan, Z.; Dong, L.; Hua, F. Correlates of smoke-free home policies in Shanghai, China. Biomed. Res. Int. 2014, 2014. [CrossRef]

7. Protano, C.; Andreoli, R.; Manini, P.; Guidotti, M.; Vitali, M. A tobacco-related carcinogen: Assessing the impact of smoking behaviours of cohabitants on benzene exposure in children. Tob. Control 2012, 21. [CrossRef] [PubMed]

8. Cheng, K.-W.; Glantz, S.A.; Lightwood, J.M. Association between smokefree laws and voluntary smokefree-home rules. Am. J. Prev. Med. 2011, 41. [CrossRef] [PubMed]

9. Yang, G.H.; Ma, J.M.; Liu, N.; Zhou, L.N. Smoking and passive smoking in Chinese. Zhong Hua Liu Xing Bing Xue Za Zhi 2005, 26, 77-83. (In Chinese).

10. Xiao, L.; Yang, Y.; Li, Q.; Wang, C.X.; Yang, G.H. Population-based survey of secondhand smoke exposure in China. Biomed. Environ. Sci 2010, 23. [CrossRef]

11. Liu, Y.; Chen, L. New medical data and leadership on tobacco control in China. Lancet 2011, 377. [CrossRef]

12. China CDC. The Global Adult Tobacco Survey (GATS) Fact Sheet China. Available online: http://www.who.int/ tobacco/surveillance/en_tfi_china_gats_factsheet_2010.pdf (accessed on 26 September 2015).

13. Burton, T.; Baker, C.L.; Mastey, V.; Mannino, D. Recent trends in exposure to second hand smoke in the United States population. BMC Public Health 2010, 359. [CrossRef]

14. Kim, E.-K.; Choo, J. Secondhand tobacco smoke exposure and associated factors among college students on campus and in the home: A preliminary study. Int. J. Environ. Res. Public Health 2012, 9. [CrossRef] [PubMed]

15. King, B.A.; Mirza, S.A.; Babb, S.D. A cross-country comparison of secondhand smoke exposure among adults: Findings from the Global Adult Tobacco Survey (GATS). Tob. Control 2012. [CrossRef] [PubMed]

16. Yang, G.H.; Hu, A.G. Tobacco Control and the Future of China: The Joint Assessment Report of Tobacco Control Situation in China; Economic Daily Press: Beijing, China, 2011. (In Chinese)

17. Chinese Center for Disease Control and Prevention. Global Adult Tobacco Survey (GATS) China 2010 Country Report. Available online: http:/ / www.notc.org.cn/newjcpg/201304/W020121108628365808856.pdf (accessed on 26 September 2015).

18. Akhtar, P.C.; Haw, S.J.; Currie, D.B.; Zachary, R.; Currie, C.E. Smoking restrictions in the home and secondhand smoke exposure among primary schoolchildren before and after introduction of the Scottish smoke-free legislation. Tob. Control 2009, 18. [CrossRef] [PubMed]

19. Ji, M.; Ding, D.; Hovell, M.F.; Xia, X.; Zheng, P.; Fu, H. Home smoking bans in an urbanizing community in China. Am. J. Prev. Med 2009, 37, 132-136. [CrossRef] [PubMed]

20. Wang, C.P.; Ma, S.J.; Xu, X.F.; Wang, J.F.; Mei, C.Z.; Yang, G.H. The prevalence of household second-hand smoke exposure and its correlated factors in six counties of China. Tob. Control 2009, 18, 121-126. [CrossRef] [PubMed]

21. Aurrekoetxea, J.J.; Murcia, M.; Rebagliato, M.; Guxens, M.; Fernández-Somoano, A.; López, M.J.; Lertxundi, A.; Castilla, A.M.; Espada, M.; Tardón, A.; et al. Second-hand smoke exposure in 4-year-old children in Spain: Sources, associated factors and urinary cotinine. Environ. Res. 2015, 145. [CrossRef] [PubMed] 
22. Lupsa, I.R.; Nunes, B.; Ligocka, D.; Gurzau, A.E.; Jakubowski, M.; Casteleyn, L.; Aerts, D.; Biot, P.; Den, H.E.; Castaño, A.; et al. Urinary cotinine levels and environmental tobacco smoke in mothers and children of Romania, Portugal and Poland within the European human biomonitoring pilot study. Environ. Res. 2015, 141. [CrossRef] [PubMed]

23. Abdullah, A.S.; Hua, F.; Xia, X.; Hurlburt, S.; Ng, P.; MacLeod, W.; Siegel, M.; Griffiths, S.; Zhang, Z.Y. Second-hand smoke exposure and household smoking bans in Chinese families: A qualitative study. Health Soc. Care Community 2012, 20, 356-364. [CrossRef] [PubMed]

24. Huang, K.Y.; Abdullah, A.S.; Huo, H.Y.; Liao, J.; Yang, L.; Zhang, Z.Y.; Chen, H.L.; Nong, G.M.; Winickoff, J.P. Chinese pediatrician attitudes and practices regarding child exposure to Secondhand Smoke (SHS) and clinical efforts against SHS Exposure. Int. J. Environ. Res. Public Health 2015, 12, 5013-5025. [CrossRef] [PubMed]

25. Wei, X.L.; Zhang, Z.Z.; Song, X.L.; Xu, Y.J.; Wu, W.; Lao, X.Q.; Ma, W.J. Household smoking restrictions related to secondhand smoke exposure in Guangdong, China: A population representative survey. Nicotine Tob. Res. 2014, 16, 390-396. [CrossRef] [PubMed]

26. Shelley, D.; Fahs, M.; Yerneni, R.; Qu, J.; Burton, D. Correlates of household smoking bans among Chinese Americans. Nicotin Tob. Res. 2006, 8, 103-112. [CrossRef] [PubMed]

27. Yao, M.; Huang, G.M.; Liang, S.L. Analysis about status quo of smoking of residents with 15 year-old and older in Guangxi, 2012-2013. Health Educ. Health Promotion 2015, 10, 8-10.

28. Bolte, G.; Fromme, H. Socioeconomic determinants of children's environmental tobacco smoke exposure and family's home smoking policy. Eur. J. Public Health 2009, 19. [CrossRef] [PubMed]

29. King, B.A.; Hyland, A.J.; Borland, R.; McNeill, A.; Cummings, K.M. Socioeconomic variation in the prevalence, introduction, retention, and removal of smoke-free policies among smokers: Findings from the International Tobacco Control (ITC) four country survey. Int. J. Environ Res Public Health 2011, 8. [CrossRef] [PubMed]

30. Zheng, P.; Berg, C.J.; Kegler, M.C.; Fu, W.; Wang, J.; Zhou, X.; Liu, D.; Fu, H. Smoke-free homes and home exposure to secondhand smoke in Shanghai, China. Int. J. Environ. Res. Public Health 2014, 11. [CrossRef] [PubMed]

31. Martinez-Donate, A.P.; Johnson-Kozlow, M.; Hovell, M.F.; Perez, G.J.G. Home smoking bans and secondhand smoke exposure in Mexico and the U.S. Prev. Med. 2009, 48, 207-212. [CrossRef] [PubMed]

32. Ting, Z.Y.; Ling, W.Y.; Shu, H.J. Household smoking restrictions among urban residents in China: Individual and regional influences. Int. J. Public Health 2015, 60, 479-486.

33. Albers, A.B.; Biener, L.; Siegel, M.; Cheng, D.M.; Rigotti, N. Household smoking bans and adolescent antismoking attitudes and smoking initiation: Findings from a longitudinal study of a Massachusetts youth cohort. Am. J. Public Health 2008, 98, 1886-1893. [CrossRef] [PubMed]

34. Schultz, A.S.H.; Nowatzki, J.; Dunn, D.A.; Griffith, E.J. Effects of socialization in the household on youth susceptibility to smoking: A secondary analysis of the 2004/05 Canadian Youth Smoking Survey. Chron. Dis. Can. 2010, 3, 71-77.

35. Wakefield, M.A.; Chaloupka, F.J.; Kaufman, N.J.; Orleans, C.T.; Barker, D.C.; Ruel, E.E. Effect of restrictions on smoking at home, at school, and in public places on teenage smoking: Cross sectional study. BMJ 2000, 321, 333-337. [CrossRef] [PubMed]

36. Shopland, D.R.; Anderson, C.M.; Burns, D.M. Association between home smoking restrctions and changes in smoking behaviour among employed women. J. Epidemiol. Community Health 2006, 60 (Suppl. 2), ii44-ii50. [CrossRef]

(C) 2016 by the authors; licensee MDPI, Basel, Switzerland. This article is an open access article distributed under the terms and conditions of the Creative Commons by Attribution (CC-BY) license (http://creativecommons.org/licenses/by/4.0/). 